\title{
Nitrogen losses from grazed dairy pasture, as affected by nitrogen fertiliser application
}

\author{
S.F. LEDGARD ${ }^{1}$, D.A. CLARK ${ }^{2}$, M.S. SPROSEN', G.J. BRIER ${ }^{1}$ and E.K.K. NEMAIA ${ }^{1}$ \\ 'AgResearch Ruakura. Private Bag 3123, Hamilton \\ ${ }^{2}$ Dairying Research Corporation, Private Bag 3123, Hamilton
}

\begin{abstract}
Inputs and losses of nitrogen $(\mathbf{N})$ were determined in dairy farmlets receiving nominally 0,200 or $400 \mathrm{~kg} \mathrm{~N} / \mathrm{ha} / \mathrm{yr}$ as urea at Dairying Research Corporation No. 2 dairy, Hamilton. In year 1, N, fixation by white clover was estimated by ${ }^{15} \mathrm{~N}$ dilution at 212,165 and $74 \mathrm{~kg} \mathrm{~N} / \mathrm{ha} / \mathrm{yr}$ in the 0 , 200 and $400 \mathrm{~N}$ treatments respectively. Removal of $\mathrm{N}$ in milk was 76, 89 and $92 \mathrm{~kg} \mathrm{~N} / \mathrm{ha}$ in the 0 , 200 and $400 \mathrm{~N}$ farmlets respectively. Loss of $\mathrm{N}$ into the air by denitrification was low $(6-15 \mathrm{~kg}$ $\mathrm{N} / \mathrm{ha} / \mathrm{yr}$ ), and increased with $\mathrm{N}$ application. Ammonia loss into the air was estimated by micrometeorological mass balance at 15, 45 and $63 \mathrm{~kg} \mathrm{~N} / \mathrm{ha} / \mathrm{yr}$ in the 0,200 and $400 \mathrm{~N}$ treatments respectively. Most of the increase in ammonia loss was attributed to direct loss after fertiliser application. Leaching of nitrate was estimated using ceramic cup samplers at $1 \mathrm{~m}$ soil depth, in conjunction with lysimeters, to be 74,101 and $204 \mathrm{~kg} \mathrm{~N} / \mathrm{ha} / \mathrm{yr}$ during the second winter when rainfall and drainage $(550-620 \mathrm{~mm})$ were relatively high. Nitrate-N concentrations in leachates increased gradually over time in the $400 \mathrm{~N}$ treatment to an average of $37 \mathrm{mg} / \mathrm{l}$ during the second winter, whereas the corresponding values for the 0 and $200 \mathrm{~N}$ treatments were 12 and 18 $\mathrm{mg} / \mathrm{l}$. Preliminary measurements of groundwater suggest that the nitrate- $\mathrm{N}$ concentration is increasing under the $400 \mathrm{~N}$ farmlet relative to the other two farmlets. Thus, the $400 \mathrm{~N}$ treatment had a major effect by greatly reducing $\mathrm{N}$, fixation and increasing $\mathrm{N}$ losses, whereas the $200 \mathrm{~N}$ treatment had relatively little effect on $N_{2}$ fixation or on nitrate leaching. However, these results refer to the first 18 months of the trial and further measurements are required over time to determine the longer-term effects of these treatments, particularly on nitrate levels in groundwater.
\end{abstract}

Keywords: ammonia loss, dairying, denitrification, groundwater, leaching, nitrogen fertiliser, $\mathrm{N}_{2}$ fixation

\section{Introduction}

The main source of nitrogen $(\mathrm{N})$ input to dairy pastures in New Zealand is from $\mathrm{N}_{2}$ fixation by white clover, which has been estimated at between 100 and $300 \mathrm{~kg} \mathrm{~N} /$ ha/yr (Ledgard et al. 1990). However, grass remains deficient in $\mathrm{N}$ for much of the year and readily responds to $\mathrm{N}$ fertiliser. Nitrogen-boosted grass growth is generally the cheapest form of "supplementary" feed and the use of $\mathrm{N}$ fertiliser by dairy farmers has increased greatly in recent years, e.g., $\mathrm{N}$ use has increased 11 -fold in Taranaki during the past 6 years (Kidd \& Howse 1994).

There have been no measurements of the effects of intensive dairy farming systems in New Zealand on several key $\mathrm{N}$ transformations and losses concomitantly, either in the absence or presence of $\mathrm{N}$ fertiliser use. However, indirect evidence suggests that nitrate leaching losses may be significant. Ad hoc surveys (Hoare 1986; Taranaki Catchment Commission 1987) of nitrate-N concentrations in groundwater in the 1970s-1980s (before the period of increasing $\mathrm{N}$ fertiliser use) showed that $20-50 \%$ of wells in the intensive dairying regions of Taranaki and Waikato exceeding the maximum acceptable level of $10 \mathrm{mg} / \mathrm{l}$ set as the $\mathrm{NZ}$ drinking water standard (Board of Health 1989). Additionally, the extent to which nitrate leaching is affected by $\mathrm{N}$ fertiliser application in NZ dairy pastures is uncertain.

The aim of the reported study was to examine $\mathrm{N}$ inputs and losses (particularly by nitrate leaching) from grazed dairy pasture, as affected by $\mathrm{N}$ fertiliser application.

\section{Methods}

Farmlets and $\mathrm{N}$ fertiliser application

A long-term farmlet trial at No. 2 dairy, Dairying Research Corporation, near Hamilton began in June 1993. Site details were given by Harris et al. (1994). Research on the fate of $\mathrm{N}$ was confined to farmlets (6.47 ha each) stocked at $3.24 \mathrm{cows} / \mathrm{ha}$ and receiving nominal rates of $\mathrm{N}$ fertiliser (urea) at 0,200 or $400 \mathrm{~kg}$ $\mathrm{N} / \mathrm{ha} / \mathrm{yr}$. Actual rates of $\mathrm{N}$ applied to measurement paddocks in year 1 were 0,225 or $360 \mathrm{~kg} \mathrm{~N} / \mathrm{ha} / \mathrm{yr}$, and were applied in 8 applications spread through all seasons except summer. 


\section{Measurements}

Detailed $\mathrm{N}$ measurements were confined to 4 replicate paddocks of each farmlet on a free-draining soil of volcanic material (Umbric Dystrochrept).

$\mathrm{N}_{2}$ fixation was determined using a ${ }^{15} \mathrm{~N}$ dilution method (Ledgard et al. 1990) with 6 replicate plots in each farmlet. Denitrification (i.e., the loss of $\mathrm{N}_{2} \mathrm{O}$ and $\mathrm{N}_{2}$ into the atmosphere caused by soil bacteria) was measured using an acetylene-inhibition technique (Ryden et al. 1987) at approximately 2-weekly intervals. Ammonia loss into the atmosphere was measured after each grazing and $\mathrm{N}$ fertiliser application using a micrometeorological mass balance method (Sherlock et al. 1989).

Leaching losses in the grazed paddocks were determined using ceramic cup samplers (30 per farmlet) located at $1 \mathrm{~m}$ soil depth. Samples of solution were collected at approximately 2 -weekly intervals and analysed for nitrate. Water drainage was determined from the volume of water passing through lysimeters containing intact soil cores $(0.4 \mathrm{~m}$ diameter, $1 \mathrm{~m}$ depth $)$ which received 0 or $400 \mathrm{~kg} \mathrm{~N} / \mathrm{ha} / \mathrm{yr}$ (4 replicates) as urea at the same time as in the $400 \mathrm{~N}$ farmlet. This drainage was also analysed for nitrate to provide estimates of $\mathrm{N}$ leaching in the absence of grazing animals.

Three wells were located in each of the farmlets to a depth of $6 \mathrm{~m}$ in March 1994. Samples of groundwater were then collected at regular intervals and analysed for nitrate.

\section{Results}

In year I, white clover production was estimated at 2770,3020 and $1650 \mathrm{~kg} \mathrm{DM} / \mathrm{ha} / \mathrm{yr}$ in the 0,200 and $400 \mathrm{~N}$ farmlets respectively. The corresponding estimates of $\mathrm{N}_{2}$ fixation were 212,165 and $74 \mathrm{~kg} \mathrm{~N} / \mathrm{ha} / \mathrm{yr}$ $(\mathrm{SED}=23)$ respectively (Figure 1). The mean proportion of total clover herbage $\mathrm{N}$ obtained from $\mathrm{N}_{2}$ fixation was 79,55 , and $46 \%$ respectively.

Milk production was 4120,4860 , and $50401 /$ cow in the 0,200 and $400 \mathrm{~N}$ farmlets respectively, and this represented the main form of $\mathrm{N}$ removal/loss (Figure 1).

Denitrification losses were increased (Figure 1, SED $=1.9)$ in the $\mathrm{N}$-fertilised farmlets but were small on an annual basis. There was a marked seasonal pattern of denitrification, almost all loss occurring during winter and spring

Ammonia loss increased by three- and four-fold in the 200 and $400 \mathrm{~N}$ farmlets respectively (Figure 1). There was no obvious seasonal pattern to the amount of ammonia loss after each grazing. Daily ammonia loss measurements indicated that over $80 \%$ of the total loss generally occurred within 4 days of grazing.
Figure 1 Nitrogen transformations in farmlets grazed by dairy cows. Data are $\mathrm{kg}$ Nha for year 1 (except for leaching which is the mean of years I and 2) and values from left to right are for 0,200 and $400 \mathrm{~N}$ treatments respectively.

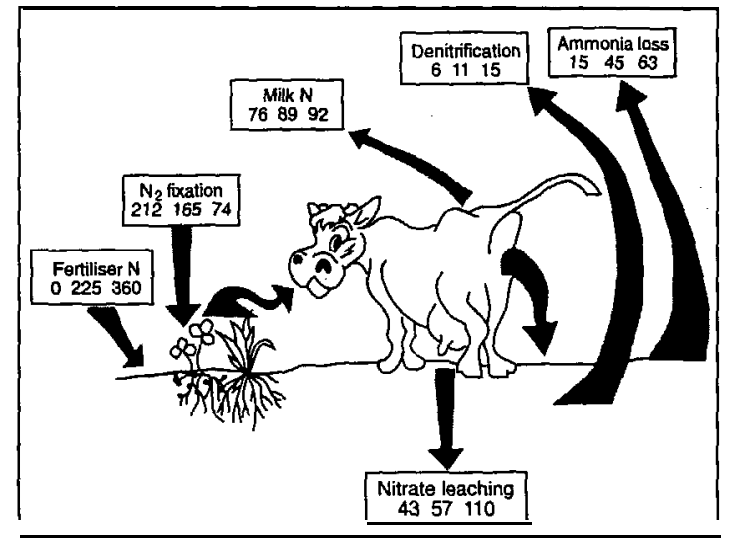

The nitrate concentration in soil solution collected at $1 \mathrm{~m}$ depth was initially similar in all treatments but differences developed over time (Figure 2). During 1993 the average concentration of nitrate- $\mathrm{N}$ was 6,6 and 8 $\mathrm{mg} / \mathrm{l}$ in the 0,200 and $400 \mathrm{~N}$ treatments respectively. The corresponding values for 1994 were 12, 18 and 37 $\mathrm{mg} / \mathrm{l}$ respectively.

Figure 2 Nitrate-N concentration of leachates sampled at $1 \mathrm{~m}$ soil depth from 0,200 and $400 \mathrm{~N}$ farmlets. The average SED was 2.8 (range I .9-4.1) in 1993 and 5.0 (range 4. 1-6.1) in 1994.

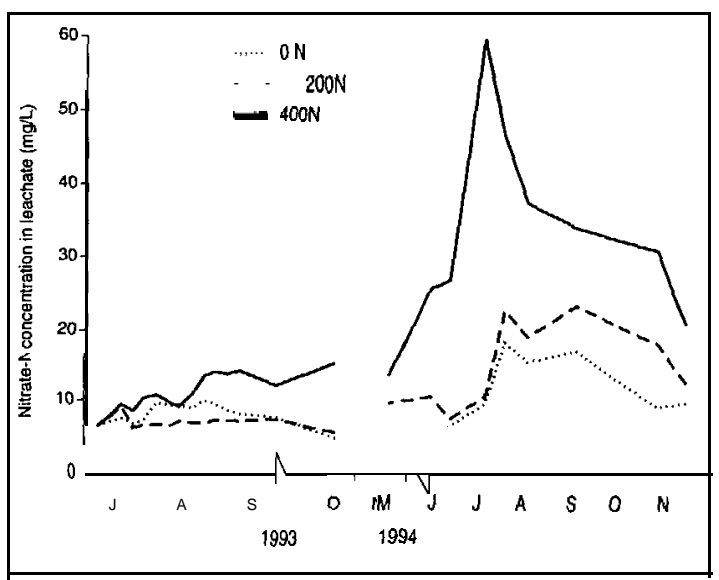

Within any one farmlet there was a wide range in nitrate-N concentrations measured between samplers. For example, during $1993,43 \%$ of the samples collected from the $0 \mathrm{~N}$ farmlet contained less than $1 \mathrm{mg} / \mathrm{l}$ nitrate- 
$\mathrm{N}$, but $28 \%$ exceeded $10 \mathrm{mg} / \mathrm{l}$ and $2 \%$ exceeded $60 \mathrm{mg} /$ I (Figure 3). In contrast, in the ungrazed lysimeters the nitrate- $\mathrm{N}$ concentrations of leachates were all between 0 and $0.3 \mathrm{mg} / \mathrm{l}$ in the $0 \mathrm{~N}$ treatment.

Figure 3 Frequency distribution of nitrate-N concentration in leachates from samplers at $1 \mathrm{~m}$ soil depth in the $0 \mathrm{~N}$ farmlet during August-October 1993.

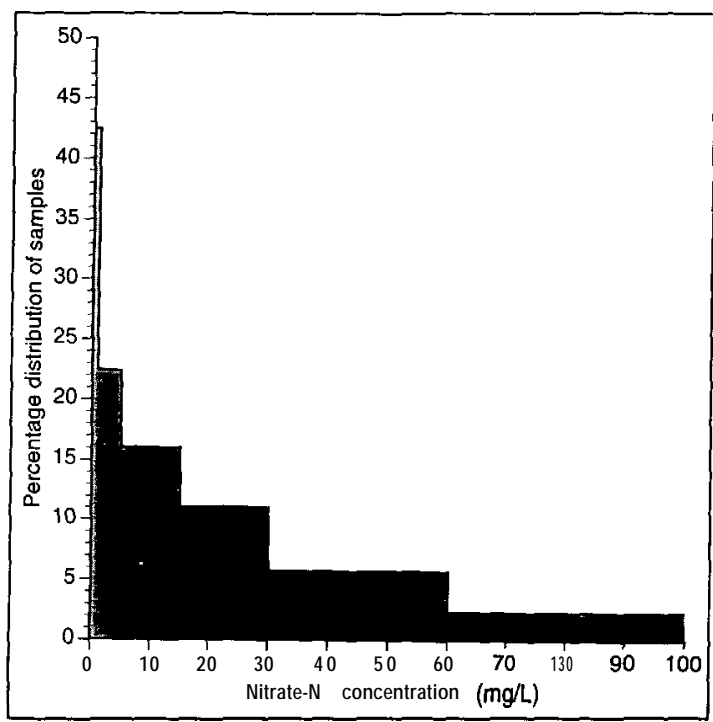

The year 1993 was relatively dry and drainage was largely restricted to June-August, whereas in 1994 drainage occurred between May and October. Total drainage measured from the lysimeters during 1993 equated to 205 and $189 \mathrm{~mm}$ in the 0 and $400 \mathrm{~N}$ treatments respectively. Corresponding drainage for 1994 was 622 and $551 \mathrm{~mm}$ respectively.

The amount of nitrate-N leached during 1993, calculated using.lysimeter water drainage, was 12,12 and $15 \mathrm{~kg} \mathrm{~N} / \mathrm{ha}(\mathrm{SED}=5)$ in the 0,200 and $400 \mathrm{~N}$ treatments respectively. The corresponding values for 1994 were 74, 101 and $204 \mathrm{~kg} \mathrm{~N} / \mathrm{ha} \quad(\mathrm{SED}=30)$ respectively.

In winter 1994 the nitrate-N concentrations in groundwater averaged 6,11 and $10 \mathrm{mg} / \mathrm{l}(\mathrm{SED}=3)$ in the 0,200 and $400 \mathrm{~N}$ treatments respectively. During spring-summer 1994 the corresponding nitrate-N concentrations were 5,10 and $20 \mathrm{mg} / \mathrm{l}(\mathrm{SED}=4)$.

\section{Discussion}

During the first year of the trial, application of $\mathrm{N}$ fertiliser in the $400 \mathrm{~N}$ farmlet reduced $\mathrm{N}_{2}$ fixation in white clover by $65 \%$. This was due to a decrease in annual clover growth of $40 \%$ as competition from associated grasses increased, and to direct substitution of uptake of fertiliser $\mathrm{N}$ for $\mathrm{N}_{2}$ fixation. In contrast, there was much less effect on $\mathrm{N}_{2}$ fixation in the $200 \mathrm{~N}$ farmlet, owing to greater amounts of pasture being carried through the summer period, thereby minimising the effects of overgrazing on clover growth which occurred in the $0 \mathrm{~N}$ farmlet. Consequently, clover growth in late-summerautumn was $140 \%$ higher in the $200 \mathrm{~N}$ farmlet than in the $0 \mathrm{~N}$ farmlet.

Nitrogen application in the $200 \mathrm{~N}$ farmlet increased milk solids production in year 1 by $16 \%$, from 1155 to $1335 \mathrm{~kg} / \mathrm{ha}$. In contrast, the $400 \mathrm{~N}$ farmlet produced only an extra $2 \%$ of milk solids relative to the $200 \mathrm{~N}$ farmlet despite $10 \%$ higher pasture DM production. This reflected adequate feeding and poor utilisation of extra pasture in the $400 \mathrm{~N}$ farmlet for the stocking rate of 3.2 cows/ha (Harris et al. 1994).

Removal of $\mathrm{N}$ in milk increased in the 200 and 400 $\mathrm{N}$ farmlets but was equal to only 6 and $5 \%$ respectively of that applied as fertiliser $\mathrm{N}$. Thus most of the increased $\mathrm{N}$ intake by cows was returned in excreta.

Loss of $\mathrm{N}$ by denitrification was low in year 1 (7-1 5 $\mathrm{kg} \mathrm{N} / \mathrm{ha}$ ) and largely confined to the winter-spring period when soil moisture was at or near field capacity. Similarly, Luoet al. (1994) measured low denitrification losses (4-6 kg N/ha/yr) from a poorly drained soil on a dairy farm near Palmerston North.

Ammonia was the main form of gaseous $\mathrm{N}$ loss, which increased markedly in the $\mathrm{N}$-fertilised farmlets (from 15 to $45-63 \mathrm{~kg} \mathrm{~N} / \mathrm{ha}$ ). Associated measurements indicated that this increase was due mainly to direct loss after fertiliser application and was equivalent to about $14 \%$ of the urea-N applied.

Leaching of nitrate from the unfertilised farmlet varied markedly between years (12 vs. $74 \mathrm{~kg} \mathrm{~N} / \mathrm{ha} / \mathrm{yr}$ in years 1 and 2 respectively). This was due mainly to a three-fold difference in the amount of drainage during winter-spring, which reflected differences in annual rainfall (893 mm vs. $1178 \mathrm{~mm} / \mathrm{yr}$ ). The large amount of $\mathrm{N}$ leached in 1994 was probably due in part to "carryover" of a high proportion of potentially-leachable $\mathrm{N}$ from the relatively dry year of 1993 (Scholefield et al. 1993).

Nitrate leaching increased in the $\mathrm{N}$-fertilised farmlets in year 2, with the largest increase at the high $\mathrm{N}$ rate. Similar effects have been measured in other studies with sheep and beef cattle (Field et al. 1985; Scholefield et al. 1993). The two possible causes of increased nitrate leaching are increased cycling and loss of excreta $\mathrm{N}$, and direct leaching of $\mathrm{N}$ from fertiliser. Cow intake of pasture $\mathrm{N}$ was estimated (using regular visual estimates of pasture cover and plant $\mathrm{N}$ analyses) to increase by about $120 \mathrm{~kg} \mathrm{~N} / \mathrm{ha} / \mathrm{yr}$ in the $200 \mathrm{~N}$ farmlet, and at least $80 \%$ of this will have been returned in excreta, 
predominantly urine. However, there was relatively little apparent change in intake between the 200 and $400 \mathrm{~N}$ farmlets, indicating that increased loss of urine $\mathrm{N}$ was only part of the cause of high nitrate leaching in the 400 $\mathrm{N}$ farmlet. Measurements of ${ }^{15} \mathrm{~N}$ recovery in plots in the farmlets revealed lower efficiency of use of fertiliser $\mathrm{N}$ at the higher rate of application (Sprosen \& Ledgard unpublished) and suggest that direct leaching of fertiliser $\mathrm{N}$ was significant in the $400 \mathrm{~N}$ farmlet.

The average nitrate- $\mathrm{N}$ concentration in leachate from grazed paddocks was much greater than that from ungrazed lysimeters and was characterised by a skewed distribution (Figure 3) with a small proportion of samples at very high concentrations (e.g., $2 \%>60 \mathrm{mg} / \mathrm{l}$ ). This was probably caused by the effect of recycling of $\mathrm{N}$ in cow urine at very high rates (e.g., $1000 \mathrm{~kg} \mathrm{~N} / \mathrm{ha}$ ) in localised patches.

Differences between farmlets in the average nitrate$\mathrm{N}$ concentration of leachates were $11-20 \%$ greater than differences in the amount of $\mathrm{N}$ leached. This occurred because $\mathrm{N}$ fertiliser enhanced pasture growth and evapotranspiration, and resulted in 8-1 7\% less drainage in the $400 \mathrm{~N}$ treatment.

There is a time lag associated with changes in activity on the land surface (e.g., $\mathrm{N}$ fertiliser application) and increased nitrate in leachate at $1 \mathrm{~m}$ depth and in the groundwater (at 3-4 $\mathrm{m}$ depth in this study) (Cameron \& Haynes 1986). This, along with variations in annual rainfall and drainage and changes in immobilisation in soil organic $\mathrm{N}$ necessitate the need for long-term measurements in order to determine the "equilibrium" effect on nitrate leaching and nitrate- $\mathrm{N}$ concentrations of leachate. Nevertheless, the extent of drainage in years 1 and $2(740-830 \mathrm{~mm})$ is equivalent to approximately 1.5 times the volume of soil water in the $\mathrm{O}-3 \mathrm{~m}$ soil depth and indicates that if leaching approximates simple "piston-flow" then the effects on groundwater nitrate-N concentration should be starting to occur (Cameron \& Haynes 1986). Indeed, groundwater monitoring suggests that there was some increase in nitrate- $\mathrm{N}$ concentration in groundwater in the $400 \mathrm{~N}$ farmlet towards the end of year 2, although further monitoring and measurements of groundwater flows are necessary to quantify any effects.

\section{Conclusions}

Results from the first year indicated that the $400 \mathrm{~N}$ rate appeared excessive for the stocking rate of 3.24 cows/ ha in that it gave little extra milk production relative to $200 \mathrm{~N}$, and the increase was unprofitable. The $400 \mathrm{~N}$ treatment also severely reduced clover growth and $\mathrm{N}_{2}$ fixation, and enhanced $\mathrm{N}$ losses. Leaching of nitrate increased steadily over time and during the second winter the average nitrate- $\mathrm{N}$ concentration of leachate at $1 \mathrm{~m}$ depth was $37 \mathrm{mg} / \mathrm{l}$ (over 3 times the $\mathrm{NZ}$ recommended limit for drinking water of $10 \mathrm{mg} / \mathrm{l}$ ) compared with $12 \mathrm{mg} / \mathrm{l}$ in the $0 \mathrm{~N}$ farmlet. Monitoring of groundwater (at 3-4 $\mathbf{m}$ depth) suggested that some increase in nitrate- $\mathrm{N}$ concentration was also beginning to occur.

In contrast, the $200 \mathrm{~N}$ treatment had only a minor impact on $\mathrm{N}_{2}$ fixation and $\mathrm{N}$ losses, while producing an $18 \%$ increase in milk production. There was relatively little effect of the $200 \mathrm{~N}$ treatment on the nitrate- $\mathrm{N}$ concentration of leachate during the first 18 months of the experiment. However, further measurements over time are needed to determine the long-term effect of $\mathrm{N}$ applications on the extent of $\mathrm{N}_{2}$ fixation and $\mathrm{N}$ losses, particularly nitrate leaching into groundwater.

\section{ACKNOWLEDGEMENTS}

We thank J.W. Penno, A.M. Bryant, K.A. Macdonald and J.A.S. Lancaster for managing the trial, $\mathrm{N}$ Selvarajah and staff for involvement in placement of wells and groundwater sampling, Dairying Research Corporation for experimental support, and FRST for funding this research.

\section{REFERENCES}

Board of Health. 1989. Drinking water standards for New Zealand. Department of Health, Wellington: $1-49$.

Cameron, K.C.; Haynes, R.J. 1986. Retention and movement of nitrogen in soils. pp. 166-241. In: R.J. Haynes (Ed.). Mineral Nitrogen in the PlantSoil System. Academic Press, New York.

Field, T.R.O.; Ball, P.R.; Theobald, P.W. 1985. Leaching of nitrate from sheep-grazed pastures. Proceedings of the NZ Grassland Association 46: 209-2 14.

Harris, S.L.; Penno, J.W.; Bryant, A.M. 1994. Effects of high rates of nitrogen fertiliser on dairy pastures and production. Proceedings of the NZ Grassland Association 56: 27-3 1.

Hoare, R.A. 1986. Groundwater nitrate in the Hamilton basin. Waikato Valley Authority Technical Report 1986/16: I-18.

Kidd, Y.; Howse, S. 1994. Farmers attitudes to nitrogen fertilisers. Proceedings of the Ruakura Farmers Conference 46: 29-35.

Ledgard, S.F.; Brier, G.J.; Upsdell, M.P. 1990. Effect of clover cultivar on production and nitrogen fixation in clover-ryegrass swards under dairy cow grazing. New Zealand journal of agricultural research 33: 243-249. 
Luo, J.; Tillman, R.W.; Bail, P.R. 1984. Nitrogen loss by denitritication from a pasture. pp. 139-151. In: L.D. Currie \& P. Loganathan (Eds.). The Efficient Use of Fertilizers in a Changing Environment: Reconciling Productivity and Sustainability. Occasional Report No. 7. Massey University.

Ryden, J.C.; Skinner, J.H.; Nixon, D.J. 1987. Soil core incubation system for the field measurement of denitritication in grassland soils. Soil biology and biochemistry 19: 753-757.

Scholefield, D.; Tyson, K.C.; Garwood, E.A.; Armstrong, A.C.; Hawkins, J.; Stone, A.C. 1993. Nitrate leaching from grazed grassland lysimeters: effects of fertiliser input, field drainage, age of sward and patterns of weather. Journal of soil science 44: 601-613.

Sherlock, R.R.; Freney, J.R.; Smith, N.P.; Cameron, K.C. 1989. Evaluation of a sampler for assessing ammonia losses from fertilized fields. Fertilizer research 21: 6 l-66.

Taranaki Catchment Commission. 1987. Nitrates in groundwater; Taranaki regional survey. Taranaki Catchment Commission, Stratford: 1-42. 